\title{
O "DESENCANTAMENTO DO MUNDO" E SUA RELAÇÃO COM A EDUCAÇÃO MODERNA
}

\author{
THE “DISENCHANTMENT OF THE WORLD” \\ AND ITS RELATIONSHIP TO MODERN EDUCATION \\ LE « DÉSENCHANTEMENT DU MONDE » \\ ET SA RELATION AVEC L'ÉDUCATION MODERNE \\ EL "DESENCANTAMIENTO DEL MUNDO” \\ Y SU RELACIÓN CON LA EDUCACIÓN MODERNA
}

Maria da Anunciação Pinheiro Barros Neta*

\section{RESUMO}

Este trabalho pretende examinar a relação entre o conceito de Weber sobre o desencantamento do mundo e a educação ocidental moderna no período da Reforma protestante. A análise do conceito weberiano e de sua relação com a educação protestante permitiu várias consideraçōes finais. Dentre outras, constatou-se que o desencantamento do mundo, no início de seu processo de racionalização, mostra-se relacionado, em boa medida, com a educação orientada pela Reforma, uma vez que a educação protestante, além de priorizar a razão humana para interpretar os princípios divinos, sem a ingerência do clero, repudia qualquer conhecimento ou atitude que se fundamente, ou mesmo lembre a magia, a feitiçaria, a bruxaria, as superstiçōes, as crenças, o dogmatismo e as tradiçôes da Igreja Católica, e se volta para uma nova prática formalista na educação.

Palavras-chave: Desencantamento do mundo. Educação moderna. História da educação.

* Doutora em Educação pela Universidade Estadual de Campinas (2006). Professora Adjunta 2 da Universidade Federal de Mato Grosso (neta@ufmt.br). 


\section{INTRODUÇÃO}

Pretende-se com este trabalho examinar a relação entre o pensamento de Max Weber (1864-1920) sobre o desencantamento do mundo e a educação ocidental moderna europeia no período da Reforma protestante.

Parte-se do pressuposto de que esse conceito formulado por Weber, enquanto processo de racionalização essencialmente religiosa, explica o surgimento do capitalismo moderno e, por conseguinte, explica também as transformações na esfera da educação que se realizaram nesse período.

Este trabalho será, portanto, desenvolvido à luz da teoria de Weber, um dos pensadores mais significativos para as Ciências Sociais e de maior influência e importância no tocante à análise do racionalismo ocidental, que se estendeu por todas as dimensões da vida social moderna.

Weber estudou o processo de racionalização subjacente à formação da sociedade capitalista e chegou à conclusão de que a diferença entre a sociedade industrial moderna e qualquer outra sociedade anterior é seu objetivo de acumular mais e mais riqueza e de aumentar indefinidamente seus bens por meio da racionalização do trabalho profissional. $\mathrm{Na}$ formação desse 'espírito capitalista', diversos fatores interferiram. Em A Ética Protestante e o Espírito do Capitalismo (1989, p. 119), Weber analisa apenas um desses fatores, a saber, a concepção de mundo e a ética do trabalho, próprias do calvinismo. ${ }^{1}$ As seitas puritanas ${ }^{2}$ são as principais representantes das religióes éticas na primeira etapa da moderna civilização do trabalho. Elas entendem que o trabalho deve ser concebido e assumido pelo homem como vocação contínua, dever absoluto, imperativo racional, organizado, metódico, sistemático e persistente, como instrumento de ascese ${ }^{3}$ voltado para o cumprimento do dever, para o cumprimento do trabalho como forma de agradar a Deus (WEBER, 1989, p. 130-131).

Para ele, esse conjunto de normas sociais e morais, representado pelo trabalho ascético, intenso e árduo, com privação do prazer e estímulo à poupança, possibilitou a reaplicação das rendas excedentes, ao invés de seu gasto perdulário em objetos materiais frívolos que remetem à vaidade e ao prestígio. Ou seja, o trabalho deve ser entendido tãosomente como meio para agradar a Deus. Foi exatamente esse ethos particular, isto é, essa maneira peculiar de organizar racionalmente o capital e de entender e praticar o trabalho que, segundo Weber, inspirou e contribuiu decisivamente para o surgimento do capitalismo. Esse sistema nasceu com base nos impulsos psicológicos e na postura ética individual rígida do puritano no que concerne à busca de fins práticos. É nesse sentido que Weber diz que o puritanismo propiciou o ethos do ascetismo próprio ao Ocidente moderno e sua função de ponte para uma era pós-tradicional, para a Modernidade (1989, p. 132).

Esse processo específico de racionalização religiosa estabelecido pela ética puritana contribuiu para o despontar da ciência e estimulou o sistema de produção racional do 
capital, que, por meio da racionalização do trabalho, desencadeou o nascimento da sociedade capitalista. Para Weber, esse é o fator essencial que determina não só a conversão de uma sociedade tradicional numa sociedade industrial, mas também todo o processo de transformação das instituiçōes sociais, políticas, jurídicas e econômicas nas sociedades ocidentais modernas (WEBER, 1989, p. 139).

No capitalismo moderno, o homem acredita que, em princípio, não existe poder enigmático que possa intervir no rumo de nossas vidas, pois o homem racional é capaz de dominar tudo mediante o conhecimento e a previsão. Para o homem moderno, não existe mais apelação a meios mágicos para dominar ou esconjurar os espíritos. Ao homem moderno cabe, agora, recorrer à técnica e à previsão (WEBER, 2004, p. 30-31).

Essa análise é central e muito importante para o presente trabalho, pois ela revela que a história do Ocidente, sobretudo a história europeia, consiste num processo de racionalização progressiva de todos os aspectos da vida organizada. E, segundo Weber, uma das características desse processo inerente à civilização ocidental reside no desencantamento do mundo.

Esse assunto é abordado em dois passos. No primeiro passo, procura-se retomar, sucintamente, o conceito de desencantamento do mundo na tentativa de deixar claro o que significa, para Weber, esse longo processo de racionalização religiosa, que inaugurou a Modernidade e estimulou o nascimento do capitalismo. Em seguida, procura-se examinar a relação entre o desencantamento e a educação moderna concretizada na Reforma protestante.

\section{CONCEITO DE DESENCANTAMENTO DO MUNDO}

Para compreender a Modernidade em Max Weber, entende-se ser importante retomar o conceito de desencantamento do mundo, por considerá-lo central na explicitação de todo o processo de racionalização por que passou a sociedade ocidental a partir dos séculos XVI e XVII.

O conceito 'desencantamento do mundo', tão insistentemente repetido e, talvez, pouco compreendido, mesmo nos meios acadêmicos, não é fácil de ser detectado nos escritos do autor. Mais que uma expressão constantemente repetida, tem um sentido denso e extenso de racionalização que perpassa vários de seus textos explicando o surgimento da Modernidade ocidental como um processo de racionalização que abrange tanto os campos econômicos, social, político, quanto científico e cultural. Mas vejamos primeiro o termo 'desencantamento'. Pierucci elucida de forma sucinta o seu significado a partir do termo alemão 'Entzauberung'.

O desencantamento do mundo, quando traduzido por desencanto e, com isso re-duzido, psicologizado nos termos de um estado mental de desilusão pessoal com o mundo (moderno) ou com os rumos da sociedade (nacional), não leva necessariamente a lugar teórico nenhum. 
Desencantamento em sentido estrito se refere ao mundo da magia e quer dizer literalmente: tirar o feitiço, desfazer um sortilégio, escapar de praga rogada, derrubar um tabu, em suma, quebrar o encantamento (PIERUCCI, 2003, p. 7-8).

Em A Ética Protestante e o Espírito do Capitalismo (2001), somente na segunda edição (1920), no capítulo segundo em que trata da ética profissional (Berufsethik) do protestantismo ascético, Weber faz uma análise do processo de racionalização do Ocidente, apoiando-se em um estudo comparativo sobre as religióes mundiais. Teria ele como finalidade mostrar a natureza cultural do processo particular que conduziu à racionalização do Ocidente, mais especificamente na Europa durante os séculos XVI e XVII, quando do nascimento de uma determinada fé religiosa, a saber, o Protestantismo.

Esse processo tem início com as ideias de Lutero, pioneiro da Reforma Protestante, que, apesar de recusar a ideia de que a Igreja detém poderes mágicos, em sua doutrina do solafideísmo afirma que os homens só poderiam ser salvos por meio da fé. A partir dessa doutrina, Lutero passa a dar maior importância ao trabalho temporal, ao exercício de uma profissão como vocação. A vocação é concedida a todos e não apenas aos monges. Para ele, a vida monástica não é merecedora da compaixão de Deus. Ao contrário, ela é ociosa e fruto do egoísmo que tende a afastar o homem do cumprimento de seus deveres terrenos (WEBER, 2001, p. 56).

Conforme Lutero, as atividades profissionais surgem como uma manifestação de amor ao próximo e todas elas são abençoadas por Deus. O cumprimento dos deveres temporais é a única maneira de agradar a Deus, e somente esta é a vontade de Deus. $\mathrm{Na}$ leitura de Weber, o conceito de vocação de Lutero não rompeu com o modelo tradicional da salvação por mérito, pois o entendimento do trabalho como vocação era aceito como determinação de Deus e, portanto, o indivíduo precisava conformar-se, submeter-se.

Weber, então, procurou identificar aspectos da ética protestante judaica com o espírito do capitalismo e passou a analisar uma possível vinculação entre os fundamentos da teoria calvinista e de outras seitas protestantes com a origem e o desenvolvimento capitalista nos países do mundo ocidental. Procurou analisar, baseado nessas seitas protestantes, o significado dessas religiōes através de alguns aspectos essenciais do capitalismo.

Para ele, o calvinismo é uma seita protestante, liderada por Calvino, que aglutina movimentos sociais, políticos e culturais de alguns países desenvolvidos economicamente, como os Países Baixos, a França, a Inglaterra, no período do século XVI ao século XVII. O calvinismo concebe um Deus completamente transcendental e com o poder de condenar ou salvar os indivíduos, de acordo com sua vontade. A teoria da predestinação calvinista reza que Deus antecipadamente escolheu certos homens à vida eterna e outros à morte eterna. Calvino acreditava ser ele próprio uma pessoa eleita por Deus e, por isso, tinha por certo sua salvação. Acreditava também que devíamos contentar em saber que Deus escolhera os homens e anjos ou para a vida eterna (escolhidos para a 
salvação), ou para a morte eterna (escolhidos para a condenação), e confiarmos nessa escolha, pois nisso consiste a verdadeira fé.

Nenhum indivíduo teria condiçōes de saber se, por meio de suas obras, seria salvo ou condenado, uma vez que elas não garantem a salvação. Essa peculiaridade do calvinismo estimulou seitas posteriores a adotar uma postura puritana, isto é, já que o indivíduo não podia contar com o perdão do padre mediante a confissão dos pecados e nem podia obter a graça divina em sua interiorização, como entendia Lutero, voltava-se para o mundo exterior e assumia a ideia de que todo e qualquer indivíduo tem o dever de trabalhar, porque o trabalho é a forma mais apropriada para prestar homenagem e ampliar a glória de Deus. Ou seja, não há mais o entendimento de que Deus está presente nesse mundo através dos indivíduos. $\mathrm{O}$ mundo é o local de trabalho para indivíduos que, ao invés de receptáculos de Deus, passam a ser seus instrumentos.

A doutrina da predestinação não era fácil de ser sustentada, pois implicava que o indivíduo permanecesse firme e constante na profissão da fé, independente de ser escolhido ou condenado. Sem se renovar, ela conservou sua prescrição, segundo a qual cada homem deveria considerar-se escolhido e lutar contra todas as dúvidas e tentações do demônio. Para lutar contra isso, era necessário perseverar no desenvolvimento da atividade secular.

Desse modo e de acordo com essa seita, o homem deveria dedicar-se com afinco ao trabalho árduo, pois o trabalho espinhoso expulsa os impulsos malignos, infetados de impurezas hedonistas ${ }^{4}$ e sensuais. O produto do trabalho, se não desfrutado pelos indivíduos, pode significar a aprovação de Deus. A implementação dessa ética cotidiana provocou a acumulação de capital e se mostrou favorável ao nascimento do capitalismo. Posteriormente, essa ética se separou da teologia, transformando-se numa força secular autônoma, apropriada ao início da estruturação do capitalismo moderno.

A ética calvinista despertou o indivíduo para agir no mundo como sujeito autônomo que procura dominar o mundo em que vive, ao invés de entregar-se ao sabor dos ventos, dos tempos, dos fatos.

Esta doutrina, na sua inumanidade patética, teve sobretudo uma consequência numa geração que se sujeitou à sua influência grandiosa: o sentimento de um isolamento interior individual inaudito. No aspecto mais decisivo para as pessoas da Reforma: a salvação eterna - o homem era obrigado a traçar o seu caminho só, face de um destino determinado desde a eternidade [...]. Era o fim do grande processo histórico-religioso do desencantamento do mundo, que se iniciou com as profecias do judaísmo antigo e que, em conjunto com o pensamento científico helênico, condenava todos os meios mágicos na procura da salvação como superstição e sacrilégio (WEBER, 2001, p. 93-94).

No calvinismo, o indivíduo já estava condenado a priori por um destino implacável, sem diminuição de dor, de peso, de trabalho. Para ele, o destino não permitia consolo 
ou alívio humano. Não tinha esperança de perdão pelas fraquezas ou imprudência de momento, como era permitida para o católico e mesmo para o protestante luterano. O comportamento do homem era racionalmente organizado e metódico. Para que ele tivesse chance de alcançar a graça de Deus, o status gratiae, ele teria que submeter o seu estado de natureza, o status naturae, a uma transformação em cada momento e em cada ação; teria que ter uma vida dirigida por uma constante reflexão.

O desencantamento do mundo, a eliminação da magia como meio de salvação, não foi levado pelo catolicismo às mesmas consequências que pelo puritanismo (e, antes, pelo judaísmo). $\mathrm{O}$ católico tinha à sua disposição a graça sacramental da sua Igreja como meio de compensação das suas insuficiências [...]. O Deus do calvinismo exige aos seus fiéis não "boas ações" isoladas, mas uma vida inteira de boas ações erigidas em sistema (WEBER, 2001, p. 101).

Os puritanos contemporâneos concebiam a ética a partir do cogito ergo sum de Descartes, isto é, sua reinterpretação ética buscava uma vida dirigida por uma permanente reflexão, baseada na conduta diária e metódica por vocação e permeada por uma racionalidade prática, visando a superação do status naturae.

Segundo Weber, o desencantamento do mundo deu à fé reconstruída sua tendência ascética e é esta a raiz de sua marcante distinção com relação à Igreja Católica. O ascetismo cristão orientava-se por um método sistemático de comportamento racional, visando a subjugar o status naturae, isto é, livrar o homem do domínio dos impulsos irracionais, do domínio do mundo e da natureza. $\mathrm{O}$ ascetismo racional cristão tentou sujeitar o homem ao domínio moral da vontade de Deus, primando pelo incessante autocontrole de suas ações. Dessa forma, ele capacitava o monge a servir a Deus e garantir a salvação de sua alma. Esse treinamento de autocontrole que subsidiava o trabalho de Santo Inácio e das virtudes monásticas racionais em geral foi igualmente o ideal prático fundamental do puritanismo.

O puritanismo e os demais tipos de ascetismo tentaram educar o homem moralmente, tornando-o apto para estar sempre vigilante, buscando adotar ações racionais e evitando a prática de impulsos e do prazer espontâneo. Essa visão de mundo é observada nas regras do monasticismo católico da mesma forma como na visão calvinista. Nesse sentido, tanto a Igreja quanto o calvinismo contribuíram para garantir a causa do Protestantismo como Igreja militante.

A distinção entre o ascetismo calvinista e o católico consiste no desaparecimento das consilia evangelica e na conversão do ascetismo em ascese, essencialmente secular. Com isto, Weber não quer dizer que no catolicismo a vida metódica, tanto teórica quanto prática, tivesse ficado restrita às celas dos mosteiros. A Igreja, embora tenha praticado maior tolerância ética, afirmava que uma vida assistemática impossibilitava a seus adeptos alcançar os ideais elevados, mesmo para um leigo. A Ordem de São Francisco constituía um exemplo, dentre tantos outros, de assumir o ascetismo na vida cotidiana. 
A prática de certas instituições religiosas, sobretudo a indulgência, encarada durante a Reforma não apenas como um abuso, mas como o pior dos males, opunha-se inevitavelmente às aspirações à ascese secular sistemática [...]. A sistematização da conduta ética que o ascetismo do protestantismo calvinista tem em comum com as formas racionais da vida monástica católica revela-se na maneira como o cristão puritano "consciencioso" controlava constantemente o seu estado de graça (WEBER, 2001, p. 103-105).

Com base na teoria da predestinação, o calvinismo trocou a aristocracia espiritual dos monges, desligada e acima do mundo, pela aristocracia espiritual dos predestinados santos de Deus, integrados no mundo.

A doutrina calvinista da predestinação foi muito consistente e surtiu efeito psicológico em todas as outras seitas subsequentes. Mesmo hoje, ela continua exercendo influência sobre os movimentos religiosos, na medida em que ora é utilizada como fonte de inspiração para ratificar seus princípios religiosos, ora é resgatada para contestar seus preceitos divergentes.

O pietismo seguiu a concepção da ética racional, sistematicamente controlada, uma vez que sua racionalidade suplantou o aspecto emocional. Ao invés da autoconfiança, que o calvinista procurava alcançar e retomar num trabalho vocacional intenso e bemsucedido, o pietismo adotou uma postura de modéstia, de renúncia e de sacrifício.

Os batistas, por sua vez, desvalorizaram os sacramentos como condição para atingir a graça divina e alcançar a salvação e realizaram a desmistificação religiosa do mundo. Destacaram-se pelo caráter eminentemente racional. Nessas seitas, todos eram responsáveis por sua vocação. A ideia de cada um ser responsável por sua vocação conseguiu, ao mesmo tempo, debilitar a concepção calvinista de vocação e aumentar a intensidade do interesse vocacional de caráter econômico.

As seitas batistas praticavam, a par dos defensores da predestinação e, sobretudo, dos calvinistas mais severos, o corte mais radical com os sacramentos. Levaram o desencantamento religioso do mundo às suas consequências mais profundas. Só a "luz interior" da revelação constante capacitava para a verdadeira compreensão da revelação bíblica de Deus. Sem a luz interna o homem natural, guiado pela razão natural, não passava de uma mera criatura, cuja distância de Deus os baptistas, e também os quaquers, ainda achavam mais abominável que os calvinistas (WEBER, 2001, p. 119).

A doutrina batista atribuiu um imenso significado ao controle por meio da consciência e possibilitou uma postura humana e profissional dirigida para o desenvolvimento de aspectos básicos do espírito do capitalismo. O princípio mais importante da ética capitalista diz que a honestidade é a melhor política, e que já encontrara o seu documento clássico no tratado de Benjamin Franklin (1732, apud WEBER, 2001, p. 121). Essa conduta ascética significou um planejamento racional de toda a vida do indivíduo, de acordo com a vontade de Deus. 
Quando da penetração do baptismo no mundo profissional secular, a ideia de que Deus só fala onde a criatura se cala significa, literalmente, uma educação do indivíduo no sentido de pesar serenamente os seus actos e na prática atenta do exame de consciência [...]. O desencantamento radical do mundo ao nível da interioridade não permitia, aliás, outra saída além do ascetismo secular (WEBER, 2001, p. 120).

Para Baxter, ${ }^{5}$ o pecado principal é a perda de tempo, pois cada hora perdida no trabalho significa perda de trabalho para a glorificação de Deus. Por isso, esse autor faz um verdadeiro sermão exaltando o trabalho físico e mental mais rigoroso juntamente com a ascese sexual, segundo a qual a relação sexual só é admitida na medida em que é desejada por Deus para o aumento de sua glória, conforme o mandamento "Crescei e multiplicai-vos". Enfim, para ele, o homem deve trabalhar energicamente em sua vocação, pois o trabalho é objetivo da própria vida e deve ser exercício para homenagear a Deus.

$\mathrm{Na}$ realidade, Weber está buscando dar a conhecer que o protestantismo ascético realizou uma união íntima e consistente entre a ação racional com relação a fins e a ação racional com relação a valores, conectando a racionalidade técnica e a racionalidade ética, mas:

Uma união de princípio, sistemática e íntegra, entre a ética profissional intramundana e a certeza de salvação religiosa, foi produzida, no mundo inteiro, somente pela ética do protestantismo ascético. Pois, neste, o mundo, em seu estado pecaminoso de criatura, tem significação religiosa exclusivamente como objeto do cumprimento dos deveres, por ações racionais, segundo a vontade de um deus absolutamente supramundano (WEBER, 1994, p. 373).

Os Quakers consideravam que o trabalho como vocação possibilita ao homem a prática da moral, que se revela na dedicação, no método, no desenvolvimento racional e consciente do trabalho. Esse destaque à especialização forneceu fundamentos para a moderna divisão do trabalho. A ética puritana chamava a atenção para uma vida racional em que até o esporte deveria prestar serviços a essa finalidade, isto é, visando uma melhor eficiência física. Condenava, por outro lado, a fruição da vida de modo espontâneo, natural e sem método. $\mathrm{Na}$ área cultural, o puritano impregnava a cultura do Renascimento, mas tinha verdadeiro horror a qualquer aspecto que lembrasse a superstição e magia a ponto de censurar as festividades cristãs do Natal e também qualquer arte (plástica ou teatral) espontânea, não científica. Para ele, cabe ao homem defender, proteger e preservar os bens culturais que Deus lhe entregou em confiança e aos quais é subjugado como administrador, ou até como máquina-de-ganhar dinheiro. Como tantos outros aspectos do moderno espírito capitalista, esse modo de conduzir a vida nasceu na Idade Média, mas só na ética do protestantismo ascético teve seus alicerces morais mais seguros:

Desencantamento/desmagificação, eticização/moralização: dois lados de uma mesma moeda, duas faces de um mesmo processo histórico-religioso que marca definitivamente a direção 
seguida pela racionalização social e cultural do Ocidente, que conforma seu caráter específico de racionalização vivida como trabalho racional, quer dizer, como dominação sistemática do mundo natural [...]. Para Weber, pois, tanto o desenvolvimento econômico-capitalista quanto o progresso científico-tecnológico precisaram da apresentação e disseminação de uma conduta de vida racional, (eine rationale Lebensführung) na medida em que, sendo ela a expressão viva de uma racionalização ética via trabalho objetivante, foi vetor de uma tomada de posição desencantada e dominadora ante o mundo natural (SCHLUCHTER, 1976, apud PIERUCCI, 2003, p. 206-207).

A ética burguesa admitia que o empreendedor burguês agisse conforme seus interesses financeiros dentro dos limites legais de correção, desde que sua conduta moral fosse ilibada e não houvesse objeção ao uso de sua riqueza. Além do mais, o poder da ascese religiosa disponibiliza trabalhadores extremamente empenhados no sentido de realizar bem as suas tarefas, de forma prudente e consciente, segundo o objetivo de vida desejada por Deus.

O trabalho é justificado como a razão da existência humana. Nesse racionalismo utilitário, há uma estreita relação entre o aspecto religioso e o racional que permeiam as relações sociais. Nessa direção, Weber entende que a racionalidade da ética protestante, alicerçada no trabalho intenso e que priva o homem do pecado do prazer, é uma espécie de motor de produção propício ao desenvolvimento inicial do espírito do capitalismo moderno, embora não queira dizer com isso que a ética religiosa tenha determinado ou originado o capitalismo:

Um dos componentes fundamentais do espírito do moderno capitalismo e, não apenas deste, mas de toda cultura moderna: a conduta racional baseada na ideia de vocação nasceu do espírito da ascese cristã [...]. O puritano queria tornar-se um profissional, e todos tiveram de segui-lo. Pois quando o ascetismo foi levado para fora dos mosteiros e transferido para a vida profissional, passando a influenciar a moralidade secular, fê-lo contribuindo poderosamente para a formação da moderna ordem econômica e técnica ligada à produção em série através da máquina, que atualmente determina de maneira violenta o estilo de vida de todo o indivíduo nascido sob esse sistema (WEBER, 1989, p. 130-131).

A ascese protestante aprofundou e valorizou a ideia do trabalho consciente, racional, ainda que por baixos salários, e acrescentou a essa noção a ideia de dever, de vocação como meio para alcançar a aprovação e a graça divina. O cumprimento do dever como vocação visando receber a graça de Deus e a ascese imposta pela Igreja, principalmente nas classes pobres, foram forças decisivas para estimular a produtividade do trabalhador moderno e a atitude aquisitiva dos empresários.

Com efeito, o comportamento racional, baseado na ideia da vocação, originou-se do espírito da ascese cristã e, na medida em que o ascetismo proporcionava mudanças significativas no mundo, os bens materiais foram adquirindo uma importância crescente para os homens, como nunca antes na História. 
O conceito de desencantamento do mundo introduzido por Weber refere-se ao desencantamento religioso do mundo pelo qual passou a sociedade ocidental em decorrência do processo de racionalização ético-ascética da postura cotidiana de vida. Desencantamento do mundo, portanto, é desmagificação religiosa. É uma forma específica de racionalização religiosa que fez surgir a Modernidade.

Weber parte de uma tipologia das formas de racionalização prática para demonstrar que a origem do processo de racionalização do Ocidente é cultural e está relacionada com a justificação ética de uma forma de conduta no mundo. Todavia, para Weber, é justamente essa dimensão fundacional do processo de racionalização que irá se perder ao longo da Modernidade. O resultado, na esfera da moral, é o surgimento do utilitarismo e, na esfera da sociedade, a cientificização dos julgamentos de valor. O primeiro resultado é que a única forma de sobrevivência da ética no mundo moderno é o utilitarismo [...]. O segundo resultado constitui a transformação da ciência em critério único para a justificação da ação [...]. No entanto, a ciência não é capaz de oferecer um critério para o julgamento entre diferentes opçōes valorativas. Daí o dilema fundamental das sociedades contemporâneas: o fenômeno da perda de sentido (AVRITZER, 2000, p. 385).

Weber estava convencido de que os novos valores sociais que faziam parte da atividade econômica capitalista não eram naturais, mas fruto do desenvolvimento histórico, assim como também os meios e os fins da atividade econômica moderna não provinham de alguma tendência universal, mas da necessidade de satisfação da sociedade como um todo.

O capitalismo moderno para Weber significa especialmente a organização do trabalho formalmente livre e de forma ordenada, racional e disciplinada. A execução dos princípios da racionalidade provoca uma força dinâmica inerente ao comportamento econômico. Um produtor não se vê agora obrigado a reduzir suas atividades quando pode elevar seus lucros em outras. As consequências desse cálculo contínuo da relação meios-fins tendem a repercutir em todas as outras instâncias da sociedade capitalista (BIRBAUM, 1994, p. 112).

A racionalidade não poderia ter ficado limitada à vida econômica. Ela deixou sua marca em todo o sistema sociocultural e em todo o sistema educacional que será analisado a seguir.

\section{A RELAÇÃO ENTRE O DESENCANTAMENTO DO MUNDO E A EDUCAÇÃO MODERNA PROTESTANTE}

A relação entre o desencantamento do mundo (enquanto processo de racionalização da civilização ocidental moderna) e a educação moderna, manifesta-se, de certa forma, desde os séculos XVI e XVII, quando da Reforma protestante tentando romper a hegemonia do Catolicismo no terreno religioso e moral e combatendo a autoridade 
espiritual da Igreja. Nessa perspectiva, acredita-se ser interessante contracenar o estágio inicial do desencantamento do mundo, isto é, a época de intensa religiosidade, que foi o século XVII, com a educação promovida pelo Movimento da Reforma protestante e seus principais expoentes.

A Reforma protestante foi o Renascimento do Norte, orientada no sentido de reformar a sociedade e a Igreja. Ela teve duas fases: uma moral e outra intelectual ou teológica. No que se refere à última, ela exaltou o julgamento individual e tornou a divisão da Igreja inevitável, uma vez que as seitas se baseavam em diferenças fundamentais sobre os tipos mentais dos homens. A primeira consequência educativa da Reforma foi elevar a razão, o direito à opinião individual e a necessidade de conhecer as fontes originais de leitura das ideias verdadeiras (MONROE, 1979, p. 172).

Decerto, os reformadores não ousaram saltar as barreiras dos dogmas incompatíveis com a razão, pois tanto quanto a Igreja Católica eles admitiram a ideia da revelação, isto é, a manifestação sobrenatural da verdade divina e sua tradição através dos séculos. A principal divergência entre católicos e protestantes está em que, para os católicos, a revelação é a verdade eterna entregue a uma instituição, no caso, a Igreja, cuja origem e autoridade, encarnadas no Papa, são divinas e infalíveis. Já para os protestantes, os dogmas revelados levam em si o direito à liberdade de análise, isto é, o crente pode e deve interpretar os Evangelhos de acordo com sua própria consciência, sem a ajuda da autoridade eclesiástica. A Reforma, portanto, coloca a instrução a serviço da fé revelada e, o conhecimento, ao abrigo da fé. Contudo, a ideia de aplicar a própria razão à verdade divina contida nos Evangelhos trouxe como consequência o exigir, de todos, a leitura da Bíblia e o exercício da razão pessoal, o que apresentou às instituiçōes educativas o problema de uma instrução geral, para todos, sem diferença de idade, sem diferença de classe social, raça ou sexo (LARROYO, 1969, p. 381).

É assim que, na Reforma protestante, movimentos populares heréticos ${ }^{6}$ trabalharam em prol da instrução, objetivando que cada indivíduo tivesse condições de ler e de interpretar a Bíblia sem a intervenção do clero, a exemplo de Comênio, ${ }^{7}$ John Wycliffe, ${ }^{8}$ na Inglaterra, e de Jan Hus, ${ }^{9}$ na Boêmia. Esse pensamento tornar-se-ia geral aos povos que se revoltaram contra a Igreja de Roma. Os movimentos populares heréticos (e não dos países católicos) pensaram e agiram a favor de projetos inovadores de instrução popular e moderna (MANACORDA, 2004, p. 194-195).

Devido à multiplicação de numerosas seitas e dos conflitos entre elas e a Igreja, a influência educativa voltou-se para um formalismo renovado, semelhante ao formalismo da escolástica. Acrescentou-se o conteúdo religioso ao humanista dominante:

O principal resultado imediato da Reforma nos países protestantes foi a transferência das escolas para o controle do Estado, a organização de sistemas do Estado e o desenvolvimento da ideia de educação universal baseada na necessidade de ler as Escrituras, catecismos e outros textos religiosos (MONROE, 1979, p. 172). 
Segundo o mesmo autor, Lutero, Melanchton e João Calvino são os principais representantes da Reforma protestante na Alemanha. Martinho Lutero (1483-1546), o grande protagonista da Reforma, assumiu a liderança do movimento educacional que tivera início na Alemanha mesmo antes que as ideias do Renascimento tivessem se desenvolvido. Tal movimento tinha três objetivos: lutava para libertar a educação do monopólio da Igreja, para divulgar as oportunidades de educação e defendia uma concepção mais verdadeira da função da educação na vida religiosa e secular (1979, p. 178).

Ainda segundo Monroe, Lutero via claramente a importância da educação geral para a Reforma e, com insistência, propalava-a em suas pregaçôes, afirmando que o ensino deveria chegar a todo o povo, nobres ou plebeus, meninos ou meninas, ricos ou pobres, e que o Estado deveria legislar em favor da frequência obrigatória. Em sua Carta às Autoridades das Cidades Alemãs, Lutero deixou registrado o seguinte:

Não posso aprovar essas escolas onde se passavam 20 ou 30 anos estudando Donato ou Alexandre, sem nada aprender. Um novo mundo surgiu onde as coisas se passam de maneira diferente. Minha opinião é que devemos enviar os meninos à escola uma ou duas horas por dia e fazê-los aprender um ofício em casa durante o resto do tempo. É desejável que estas duas ocupaçōes andem lado a lado (apud MONROE, 1979, p. 179).

Filipe Melanchton (1479-1560) foi o mais destacado mestre da Reforma alemã. Seus vastos conhecimentos e profunda influência na cultura alemã renderam-lhe o título imortal de Preceptor da Alemanha. A Universidade de Wittenberg foi reestruturada conforme as ideias humanistas e protestantes, tornando-se o modelo de muitas universidades da Alemanha. Seus livros sobre dialética, retórica, ética e física foram adotados nas escolas elementares e sua teologia tornou-se destacado livro didático para as universidades e escolas superiores protestantes (MONROE, 1979, p. 179-180).

João Calvino (1509-1564): nome algum na história da Igreja tem sido tão amado e odiado, admirado e detestado, elogiado e condenado, abençoado e amaldiçoado, como o de João Calvino. A maioria dos reformadores era educadora, tanto na Alemanha, quanto na Suíça, França, Holanda e Escócia. Calvino dá ao protestantismo francês sua doutrina e organização. Mais rigoroso que Lutero, suas ideias se propagaram na Holanda e Bélgica, de forma intensa e imediata. O calvinismo foi uma revolução mental e espiritual. Ele se tornou mais que uma teologia, foi uma ideologia que não respeitou fronteiras nacionais ou tradiçôes (EBY, 1976, p. 81).

A doutrina de Calvino está exposta, sobretudo, no livro Instituição Cristã. Seu ponto de partida é o mesmo de Lutero. Calvino só admite, em termos de religião, a autoridade da Bíblia, e garante que apenas a fé pode salvar o homem, e não as obras. Contudo, partindo da ideia da onipotência e onisciência divinas, ele afirma que a fé é dom especial que Deus concede aos eleitos desde a eternidade. Essa é a doutrina da predestinação. Sua obra educativa foi importante. Criou várias escolas primárias e promoveu uma reforma 
moral dos cidadãos. Calvino adquiriu de Santo Agostinho o pessimismo moral, motivo fundamental em todas as suas doutrinas religiosas e planos para a educação. Segundo seu modo de pensar, a criança é má. Sua depravação é total, todos os elementos de sua natureza, como emoções, razão e vontade, são igualmente perversos, todas as suas inclinações naturais, infantis, apetites e interesses propiciam sua perversão. Portanto, no interesse da vida moral e religiosa todos esses elementos devem ser eliminados e, em seu lugar, encaixados bons hábitos e pensamentos bons. A ideia da educação primária obrigatória teve excelentes resultados em todos os países protestantes (EBY, 1976, p. 82).

Posteriormente a Lutero, Melanchton e Calvino, outras iniciativas de educação popular foram desenvolvidas. No século XVII surgiu o esboço da pedagogia científica que só veio a constituir-se após a formação das ciências humanas no século XIX, e surgiu também a clara consciência da necessidade da didática embasada cientificamente, e nesse esforço se percebe o deslocamento, para o ambiente escolar, das preocupações metodológicas dos cientistas nas suas atividades de campo ou de laboratório. Além disso, com o progresso das ciências experimentais e das matemáticas, essas novas disciplinas precisaram ser integradas no currículo escolar, que até então era predominantemente humanístico ou literário (EBY, 1976, p. 87).

O Pietismo: corrente religiosa criada no final do século XVII, por Philipp Jacob Spener (1634-1705). Essa corrente se caracteriza por contestar a Reforma religiosa que (a princípio lutou contra uma concepção intelectualista do Cristianismo) vinha se transformando em uma espécie de Teologia escolástica, ${ }^{10}$ mais atenta à explicação racional dos dogmas do que aos valores emotivos da religiosidade humana. Esse Cristianismo sincero e prático rejeita os prazeres do mundo, como festas, jogos, excessos no vestir, brinquedos infantis, gracejos, teatro, leitura de romances e até jornais. Nesse sentido, os pietistas uniram a insistência de Lutero no estudo das escrituras, oração e fé, com a insistência de Calvino no puritanismo da conduta (EBY, 1976, p. 213).

Augusto Hermann Francke (1663-1727) foi o mais célebre exemplo de educador prático cristão da Alemanha. Completou e desenvolveu postulados da Pedagogia pietista que criou o Pädagogium, fundou uma Escola Latina ou ginásio humanista, construiu também, em Frankfurt, Escolas Normais (Seminarium praeceptorum), e fundou a Hospedaria, onde meninas e meninos abandonados recebiam as primeiras noçōes do ensino elementar, instituindo também pequenas Escolas para Pobres e Orfanados. Nessas escolas, o ensino das disciplinas científicas desenvolveu gradativamente e era ministrado juntamente com práticas recreativas, como as visitas às oficinas dos artesãos (NUNES, 1981, p. 97).

A instrução popular, idealizada pela Reforma, foi se efetivando na Alemanha com a primeira criação das escolas de vila (Dorfschulen), em 1642, no Estado de Gotha, e as escolas para os pobres, em 1695, em Halle. Essa instrução popular foi sendo concretizada posteriormente com a decretação da obrigatoriedade de fundar as Dorfschulen no reino da Prússia, sob o governo de Frederico Guilherme I, em 1717, e com o surgimento das 
escolas científico-técnicas (Realschulen) em Berlim, em 1747. Tais iniciativas escolásticas estatais, sobretudo na Alemanha, são as bases políticas do moderno sistema de instrução obrigatória do Estado dirigido para os estudos científico-técnicos. De qualquer modo, as iniciativas mais inovadoras foram realizadas pelos puritanos na Inglaterra, através de escolas voltadas para a aprendizagem de conteúdos científicos e técnicos, em virtude de atividades trabalhistas ligadas às transformaçôes que vinham ocorrendo nos modos de produção (MANACORDA, 2004, p. 235).

\section{CONSIDERAÇÕES FINAIS}

Com base na análise acima, pode-se concluir que a história do Ocidente na Modernidade, principalmente a história da Europa, baseia-se num extenso processo de racionalização identificado por Weber como desencantamento do mundo, nascido das seitas puritanas e que romperam com a magia, a feitiçaria e a bruxaria, propiciando o surgimento do capitalismo moderno.

Nessa perspectiva, observa-se que o ponto de partida do desencantamento do mundo, isto é, a eliminação da magia como meio de salvação, mostra-se, em boa medida, relacionado com a educação fomentada pela Reforma protestante, uma vez que:

A educação norteada pela Reforma buscou romper com a concepção de mundo propagada pela Igreja Católica, que concebia o conhecimento humano baseado nos dogmas da Igreja e para a qual só é possível demonstrar a verdade de Deus intermediada pela leitura das autoridades da Igreja (Papa, bispo, padre, dentre outras). A educação pensada e executada pelos protestantes, em geral, embora aceitasse a ideia de revelação, entendia que o homem é um ser racional, e, como tal, deve fazer sua própria interpretação acerca dos princípios divinos, sem a ingerência do clero;

A educação protestante, além de priorizar a razão humana, mostrava-se avessa a qualquer conhecimento ou atitude que se fundamentasse, ou mesmo lembrasse, a magia, a feitiçaria, a bruxaria, as superstições, as crenças, o dogmatismo e as tradições da Igreja Católica, e se voltava para uma nova prática formalista na educação (análoga ao formalismo escolástico), que exigia intenso rigor no cumprimento de normas e/ou princípios estabelecidos (semelhante às normas e princípios adotados na racionalização econômica, que se caracteriza pelo trabalho cotidiano árduo, penoso, sistemático, exercido exclusivamente para agradar a Deus);

O desencantamento do mundo mostra-se relacionado novamente, com algumas ideias educacionais mais específicas de Martinho Lutero, Melanchton e João Calvino, na medida em que o primeiro, que liderou o movimento educacional na Alemanha, lutou para tornar a educação independente do controle exclusivo da Igreja e, em suas pregaçóes, mostrava a importância da educação, não apenas para os monges e nobres (como entende a Igreja Católica), mas pregava sua extensão generalizada (independente 
de classe social ou de sexo) para que cada indivíduo tivesse condições de ler a Bíblia racionalmente, sem a interferência de outra visão, de outro entendimento;

Melanchton foi o principal mestre da Reforma alemã e, graças a ele, grande parte dos protestantes da Alemanha conseguiu superar o catolicismo no campo da cultura e da educação;

João Calvino criou várias escolas primárias e elaborou uma teoria para a educação com o fim de realizar a reforma moral dos indivíduos. Como já foi dito, a criança é má por natureza e todas as suas emoções, interesses e vontades naturais proporcionam sua desmoralização. Esses elementos naturais devem ser trocados por atitudes e pensamentos bons, isto é, que as levem a agir com racionalidade, prudência, perseverança e circunspeção. Como podemos ver, essa ideia de educação calvinista guarda estreita relação com algumas de suas ideias religiosas, como a racionalidade imposta ao trabalho, em que o indivíduo, para alcançar a graça divina (status gratiae) precisa subjugar o seu estado de natureza (status naturae), isto é, subjugar os instintos irracionais a uma contínua e rigorosa reflexão. A teoria da predestinação sustentava que o homem é salvo ou condenado segundo a livre onipotência e eterna vontade de Deus. O homem, portanto, só deve confiar em ter sido eleito exercendo uma vida digna de acordo com essa esperança, visto que a livre eleição de Deus deve basear-se na coerência racional entre salvação e vida;

O desencantamento do mundo mostra-se relacionado também, em traços bem precisos, com outras correntes educacionais desenvolvidas no século XVII. O Pietismo, por exemplo, uma espécie de cristianismo prático, manifesta essa relação, na medida em que procurou conciliar a perseverança de Lutero no estudo das Sagradas Escrituras, oração e fé com a rigidez moral de Calvino que abominava o consumo desnecessário e toda espécie de prazer, seja ele oriundo de brincadeiras infantis, de jogos, teatro, música, inclusive o prazer proporcionado pela leitura de jornais. Hermann Francke, principal educador prático cristão, criou várias escolas com a preocupação de instigar o ensino das ciências;

O desencantamento do mundo se manifesta relacionado ainda à criação de algumas escolas populares, sobretudo na Alemanha, na medida em que elas fomentaram do ponto de vista político, o moderno sistema de ensino estatal voltado para o estudo de conteúdos científicos e técnicos, em virtude das atividades vinculadas às transformações nos modos de produção. 


\section{Notas}

1. Doutrina criada por João Calvino (1509-1564), um dos principais reformadores protestantes.

2. Doutrinas reformistas mais rigorosas que as demais seitas protestantes, que pretendiam interpretar melhor que ninguém o sentido literal das Escrituras e eram muito rígidas na aplicação dos princípios morais metodicamente racionalizados.

3. Exercício prático que leva à efetiva realização da virtude, à plenitude da vida moral.

4. Partidário do hedonismo, doutrina que considera o prazer individual e imediato como o único bem possível, princípio e fim da vida moral.

5. Richard Baxter (1615-1691), um dos líderes do puritanismo inglês, é autor do Christian Directory, o mais completo compêndio da teologia moral puritana, inteiramente orientado pela experiência prática de seu ministério.

6. Indivíduos pertencentes à seita religiosa contrária ao que foi definido pela Igreja em matéria de fé.

7. Jan Amos Komenski (1592-1670), filósofo tcheco considerado o primeiro grande nome da moderna história da educação. Combateu o sistema medieval e defendeu o direito de todas as pessoas à educação. Didácta Magna, sua obra mais importante, marca o início da sistematização da pedagogia e da didática no Ocidente.

8. Nasceu, viveu e estudou na Inglaterra no século XIV (1320-1384), onde desenvolveu uma "teoria da comunidade invisível dos eleitos" e defendeu a devolução dos bens eclesiásticos ao poder temporal, encarnado pelo soberano.

9. Nasceu em 1373 na Boêmia, onde estudou, ordenou-se e adquiriu grande popularidade com seus sermóes carregados de críticas aos abusos eclesiásticos. Foi condenado pelo Concílio de Constança e queimado em 1415.

10. Doutrina teológico-filosófica dominante na Idade Média, caracterizada, sobretudo, pelo problema da relação entre a fé e a razão, problema que se resolve pela dependência de pensamentos filosóficos representados pela filosofia greco-romana, da teologia cristã.

\section{Referências}

AVRITZER, Leonardo. Habermas e Weber: da instrumentalização da moral aos fundamentos morais da democracia. In: SOUZA, Jessé (Org.). A atualidade de Max Weber. Brasília: Edunb, 2000, p. 373-393.

BIRNBAUM, Norman. Interpretaçôes conflitantes sobre a gênese do capitalismo: Marx e Weber. In: GERTZ, René E. (Org.). Max Weber \& Karl Marx. Trad.: René E. Gertz. São Paulo: Hucitec, 1994. p. 99-119.

EBY, Frederick. História da educação moderna: teoria, organização e práticas educacionais. Trad.: Maria Ângela Vinagre de Almeida, Nelly Aleotti Maia, Malvina Cohen Zaide. 2. ed. Porto Alegre: Globo, 1976.

FRANKLIN, Benjamin. Poor Richard's Almanac. Philadélphia: Pennsylvania Gazette, 1732.

LARROYO, Francisco. História geral da pedagogia. São Paulo: Metre Jou, 1969, 2 volumes. 
MANACORDA, Mario Alighiero. História da educação: da antiguidade aos nossos dias. Trad.: Gaetano Lo Mônaco, 11. ed. São Paulo: Cortez, 2004.

MONROE, Paul. História da educação. 14. ed. São Paulo: Nacional, 1979.

NUNES, Rui Afonso da C. História da Educação no Século XVII. São Paulo: EPU: Edusp, 1981.

PIERUCCI, Antônio Flávio. $O$ desencantamento do mundo: todos os passos do conceito em Max Weber. São Paulo: USP, Curso de Pós-Graduação em Sociologia. Ed. 34, 2003.

WEBER, Max. A ética protestante e o espírito do capitalismo. Trad.: M. Irene de Q. F. Szmrecsányi e Tamás J. M. K. Szmrecsányi. 7. ed. São Paulo: Pioneira, 1989.

. A ética protestante e o espírito do capitalismo. Trad.: Ana Maria Falcão e Luis Leitão. Lisboa: Presença, 2001.

Economia e sociedade: fundamentos da sociologia compreensiva. Trad.: Regis Barbosa e Karen Elsabe Barbosa. 3. ed. Brasília: Edunb, vols. I, 1994 e II, 1999.

. Ciência e política: duas vocações. 18. ed. São Paulo: Cultrix, 2004. 


\section{The "disenchantment of the world" and its relationship to modern education}

\section{Abstract}

The main objective of this paper is to investigate the relationship between Max Weber's concept of the disenchantment of the world and the modern occidental education during the Protestant Reformation. The analysis of his concept and its relationship with protestant education allowed for several final considerations. Among other things, it was verified that the disenchantment of the world, at the beginning of its process of rationalization, is closely related to the education oriented by the Reformation, considering that the Protestant Educational System, besides giving priority to the human rationalism to interpret the divine principles, without the interference of the clergy, rejected any knowledge or attitude which supported, or even suggested any kind of relation to magic, sorcery, witchcraft, superstitions, beliefs, the dogmatism and the traditions of the Catholic Church. And so a new formalist educational practice is adopted.

Keywords: Disenchantment of the world. Modern education. History of education.

\section{Le « désenchantement du monde » et sa relation avec l'éducation moderne}

Résumé

Ce travail prétend examiner la relation entre le concept de Weber sur le désenchantement du monde et sa relation avec l'éducation moderne occidentale dans la période de la Réforme protestante. L'analyse du concept weberien et de sa relation avec l'éducation protestante, a permis plusieurs considérations finales. Entre autre, il a été constaté que le désenchantement du monde, au début de son processus de rationalisation, se révèle en relation, en grande mesure, avec l'éducation orientée par la Réforme, une fois que l'éducation protestante, en plus de prioriser la raison humaine pour interpréter les principes divins, sans l'ingérence du clergé, répudie toute connaissance ou attitude qui se fonde, ou même fait penser à la magie, le fétiche, la sorcellerie, les superstitions, les croyances et les traditions de l'Église Catholique et se tourne vers une pratique formaliste dans l'éducation.

Mots clefs : Désenchantement du monde. Éducation moderne. Histoire de l'éducation.

\section{El “desencantamiento del mundo” y su relación con la educación moderna Resumen}

Este trabajo intenta examinar la relación entre el concepto de Weber sobre el desencantamiento del mundo y la educación occidental moderna en el periodo de la reforma protestante. El análisis del concepto weberiano y de su relación con la educación protestante permitió varias consideraciones finales: se constató que el desencantamiento del mundo, en el inicio de su proceso de racionalización, se muestra relacionado, en gran parte, con la educación orientada por la reforma, una vez que la educación protestante, además de priorizar la razón humana para interpretar los principios divinos sin la interferencia del clero, repudia cualquier conocimiento o actitud que se fundamente o esté relacionado a la magia, a la hechicería, a la brujería, a las supersticiones, a las creencias, al dogmatismo y a las tradiciones de la iglesia católica y se vuelve para una nueva práctica formalista en la educación.

Palabras-clave: Desencantamiento del mundo. Educación moderna. Historia de la educación.

Recebido em: 15.04 .2008

Aceito em: 05.05.2009 